\title{
Endoparasitoses in hospitalised paediatric patients with pulmonary disease
}

\author{
P. JURIŠ ${ }^{1}$, A. DUDLOVÁ ${ }^{1}$, J. FÁBRY ${ }^{2}$, J. MELTER ${ }^{2}$, M. MIŠKOVSKÁ ${ }^{2}$, E. MINDŽÁKOVÁ ${ }^{2}$, P. JARČUŠKA ${ }^{1}$, \\ V. KRČMÉRY ${ }^{4}$, L. ČISLÁKOVÁ ${ }^{1}$, I. PAPAJOVÁ ${ }^{3}$, D. SYSEL ${ }^{5}$
}

\begin{abstract}
${ }^{1}$ Faculty of Medicine, Pavol Jozef Šafárik University in Košice, Šrobárova 2, 041 80, Košice, SR, E-mail: juris.peter777@gmail.com; ${ }^{2}$ Clinic of Paediatric Tuberculosis and Respiratory Diseases, Jessenius Faculty of Medicine in Martin, Comenius University in Bratislava and Šrobár Institute of Paediatric Tuberculosis and Respiratory Diseases, Dolný Smokovec, SR, E-mail: fabry@sudtarch.sk; ${ }^{3}$ Institute of Parasitology, SAS, Hlinkova 3, 04001 Košice, SR, E-mail: papaj@saske.sk $;{ }^{4}$ St. Elizabeth College of Health and Social Work, Bratislava, SR, E-mail: tropicteam@gmail.com; ${ }^{5}$ Faculty of Medicine, Comenius University in Bratislava, Špitálska 24,
\end{abstract} 81372 Bratislava, E-mail: dusan.sysel@fmed.uniba.sk

\begin{abstract}
Summary
Faeces examination of hospitalised paediatric patients with respiratory diseases (recurrent and chronic bronchitis, bronchial asthma, contact with TBC, active TBC, rhinopharyngitis, bronchitis, pneumonia, cystic fibrosis, fluidothorax, pleuropneumonia) revealed the total prevalence of endoparasites of $19.85 \%$, out of which the prevalence of helminth was $7.35 \%$. Following genera, or species were represented Ascaris lumbricoides, Trichuris trichuria, Hymenolepis spp., Enterobius vermicularis. The total prevalence of protozoa was $12.50 \%$ in the following representation: Cryptosporidium spp., Entamoeba spp., Isospora spp., Giardia spp. Out of helminthoses the greatest representation was in Ascaris lumbricoides $4.41 \%$, and out of protozoa Cryptosporidium spp. $6.62 \%$. In paediatric patients the increased levels of IgE antibodies were found for individual age groups as well as higher values of eosinophiles (Eo $>5 \%$ ), lymphocytes ( $\mathrm{Lym}>56 \%$ ), and Creactive protein $\left(\mathrm{CRP}>8 \mathrm{mg} \cdot \mathrm{l}^{-1}\right)$. Statistically significantly $(\mathrm{P}<0.05)$ higher level (above the reference values) of IgE, Eo, Lym were found in the patients with helminthoses.
\end{abstract}

Key words: endoparasitosis; helminths; protozoa; bronchial and pulmonary infections of children; prevalence; epidemiology

\section{Introduction}

Worldwide spread intestinal parasitic infections belong among the most serious health problems in humans in tropical and subtropical regions. Under our climatic-geographical regions it concerns especially people with weak socio-economic standard living in the environment with low hygiene (personal and also environmental). In Slovakia it is most pronouncedly manifested in the Romany settlements and communities (Juriš et al., 2012). The causes of the worsened health status also lie in the absence of drinking water and sewerage system, bad housing, missing infrastructure, unhealthy feeding, bad personal hygiene, and neglected communal hygiene. In the children living in such conditions there is higher incidence of infectious diseases conditioned by the environmental risks. In general, it can be stated that the health status of the children living in the environment of lower hygienic standard is worse compared to the majority population in Slovakia (Rimárová, 2010). Intestinal parasitism is regarding the health of an individual often connected with the manifestation of allergic reactions and immunodeficient states, especially in paediatric patients within the lowest age group ( $1-5$ years). Children suffering from various respiratory diseases connected with immunodeficient status are often positive to some opportune helminth infections (Kalu et al., 2013). Larval stages of tissue helminthoses of the genera Ascaris and Toxocara after migration through the pulmonary tissue within entero-hepato-pulmonary migration can cause so-called eosinophilic pneumonitis. The clinical picture of the acute phase is accompanied with fever, asthmatic attacks of cough. In $30 \%$ of infected patients, there are pulmonary infiltrates, slight hepatopathy, lymphadenopathy and urticaria. In the blood picture there is leucocytosis, eosinophilia ranges from 10 to $90 \%$; as well, immunoglobulins above all, of the class IgE and IgG could be elevated (Beneš et al., 2009).

The goal of the study was the ovoscopic diagnostics of endoparasitic infections (protozoa and helminths) in hospitalised paediatric patients.

\section{Material and methods}

In our study in total 272 paediatric patients were examined coprologically (147 boys and 125 girls) from the Šrobár Institute of paediatric tuberculosis and respiratory diseases in Dolný Smokovec with pulmonary disease of infectious 
Table 1a Prevalence (P \%) of protozoa and helminths in paediatric patients with infection disease of the lower airways

\begin{tabular}{lcc}
\hline Parasites & (No. 272) & P \% \\
\hline Protozoa and helminths & 54 & 19.85 \\
Protoza & 34 & 12.50 \\
Helminths & 20 & 7.35 \\
Negative samples & 218 & - \\
\hline No. - number of samples & &
\end{tabular}

Table 1b Prevalence (P \%) of protozoa and helminths in different age groups of paediatric patients with infection disease of the lower airways

\begin{tabular}{lccccc}
\hline Age group & $\begin{array}{c}\text { Examined samples } \\
(\text { No. 272) }\end{array}$ & \multicolumn{2}{c}{ Protozoa } & \multicolumn{2}{c}{ Helminths } \\
\cline { 3 - 6 } & & $\begin{array}{c}\text { Positive } \\
(\text { No. 34) }\end{array}$ & P $\%$ & $\begin{array}{c}\text { Positive } \\
(\text { No. 20) }\end{array}$ & P \% \\
\hline $1-5$ years & 57 & 5 & 8.77 & 7 & 12.28 \\
6-10 years & 110 & 8 & 7.27 & 8 & 7.27 \\
$11-16$ years & 105 & 21 & 20.00 & 5 & 4.76 \\
\hline
\end{tabular}

and non-infectious etiology. In the population studied there were 15 children of Romany origin. The analysis was carried out in three age groups: group $1-5$ years (57 patients), group $6-10$ years (110 patients), group $11-16$ years (105 patients). The copro-ovoscopic concentration set Paraprep L - Faecal Parasite Concentrator (Diamondial, France) with subsequent microscopy were used for coprological examination of the presence of oocysts and ova in samples. The blood and sera of the children examined were processed by the standard laboratory procedures. The values of immunological and haematological findings were compared with the reference values in children according to the diagnostic laboratory Labmed. Statistical evaluation of the results was carried out using the x-test (significance level $\alpha=0.05$ ) by the statistical programme SPSS.

\section{Results}

Children faeces examination revealed the total prevalence of endoparasitoses of $19.85 \%$, out of which helminth infections were $7.35 \%$ (see Table 1a). The total prevalence of protozoa occurrence was $12.50 \%$ in representation of
Cryptosporidium spp., Entamoeba spp., Isospora spp. and Giardia spp. The highest prevalence of protozoal infections was in the children of the age group of $11-16$ years $-20 \%$, and helminth infections in those of the age group of $1-5$ years $-12.28 \%$ (see Table $1 \mathrm{~b}$ ).

From the table 2 it follows that out of the helminths in faeces samples following species were represented: $A s c a-$ ris lumbricoides, Trichuris trichuria, Hymenolepis spp., Enterobius vermicularis. A. lumbricoides had the highest representation of helminthoses $(4.41 \%)$ and Cryptosporidium spp. of protozooses $(6.62 \%)$ (see Table 2$)$.

In the paediatric patients observed the clinical units of the respiratory tract were represented, from simple rhinopharyngitis to more serious inflammatory diseases of lungs and pleura. It is interesting that at serious pleuropneumonia and fluidothorax in two patients there was no other except for positive ovoscopic finding of $A$. lumbricoides eggs in faeces (see Table 3 ).

Serological examination in paediatric patients revealed the increased levels of reference values of $\operatorname{IgE}$ antibodies ( $\mathrm{IgE}$ $>15,>60,>90,>200 \mathrm{IU} / 1$, for individual age groups), eosinophils (Eo $>5 \%$ ), lymphocytes (Lym $>56 \%$ ), and $\mathrm{C}$-reactive protein $\left(\mathrm{CRP}>8 \mathrm{mg} / \mathrm{l}^{-1}\right)$. These findings are

Table 2. Representation of protozoa and helminths in positive faecal samples of hospitalised paediatric patients

\begin{tabular}{lcc}
\hline Parasites & $\begin{array}{c}\text { Positive samples } \\
\text { (No. 54/272) }\end{array}$ & $\begin{array}{c}\text { Prevalence } \\
\text { P \% }\end{array}$ \\
\hline Cryptosporidium spp. & 18 & 6.62 \\
Entamoeba spp. & 8 & 2.94 \\
Isospora spp. & 2 & 0.74 \\
Giardia spp. & 9 & 3.30 \\
Ascaris lumbricoides & 12 & 4.41 \\
Trichuris trichuria & 3 & 1.10 \\
Hymenolepis spp. & 5 & 1.84 \\
Enterobius vermicularis & 2 & 0.74 \\
\hline
\end{tabular}


in agreement with coprological findings of eggs (see Table 3 and 4). Statistically significant differences $\left(\chi^{2}, \mathrm{P}<0.05\right)$ were found in the levels of eosinophils (Eo) and lymphocytes (Lym) that were increased above the reference values in the patients positive and negative to heminthoses. The increased levels of IgE were statistically significantly higher in the patients positive to helminthoses (in $40 \%$ positive patients and $20 \%$ negative ones). The increased levels of Eo were in $45 \%$ positive patients and in $23 \%$ negative ones. As well, the increased levels of Lym were recorded in $40 \%$ positive patients and in $31 \%$ negative ones (see Table 4). personal hygiene. The groups of children population living under conditions of lower socio-economical standard belong to the most endangered. The faecal pollution of the environment represents for such patients a significant health risk, because contaminated environment with cysts (e.g. Gardia spp., T. gondii and oocysts Cryptosporidium spp.), or helminth eggs (Ascaris spp., Toxocara spp., Hymenolepis spp.) often becomes the source of parasitic infections (Rudohradská et al., 2012). Under the environmental conditions the developmental stages of endoparasites are resistant against routinely used disinfectant preparations (Ondrašovič et al., 2002).

Table 3 Respiratory diagnoses in examined children

\begin{tabular}{lcc}
\hline Diagnosis & Number of children & P \% \\
\hline Recurrent and chronic bronchitis & 109 & 40.07 \\
Bronchial asthma & 77 & 28.31 \\
Contact with TBC & 34 & 12.50 \\
Active TBC & 27 & 9.93 \\
Rhinopharyngitis recurrent & 9 & 3.31 \\
Acute bronchitis & 8 & 2.94 \\
Pneumonia & 5 & 1.84 \\
Cystic fibrosis & 1 & 0.37 \\
Fluidothorax & 1 & 0.37 \\
Pleuropneumonia & 1 & 0.37 \\
\hline Total & $\mathbf{2 7 2}$ & $\mathbf{1 0 0 . 0 0}$ \\
\hline
\end{tabular}

\section{Discussion}

According to Chaudhry et al. (2004) in children older than 2 years the prevalence of parasitoses decreases with increasing age. This follows also from our results, when the prevalence of helminthoses in our patients decreased, however, in protozoal infections the increase was recorded in older patients. Kalu et al. (2013) recorded the highest occurrence of nematodes in the age group of $6-8$ years. O'Harhay et al. (2010) observed in A. lumbricoides and $T$. trichuria very similar course with the increase of prevalence from childhood to adolescent age, and decreasing trend in adulthood.

In our children examined the prevalence of intestinal nematodes with increasing age decreased. The reason can be in the higher immune response in older children as well as in their intentional acquiring hygienic habits including
Paediatric patients with weakened immune system are susceptible to various infections of the respiratory system. The cause could be in the great amount of serotypes of viruses and bacteria. Helminths often belong among the opportune pathogens that attack the organisms of patients with serious respiratory disease (Shuji et al., 2006).

Königová et al. (2010) found in paediatric patients at the age of 9 months up to 16 years with acute or chronic respiratory and gastrointestinal infection the occurrence of $A$. lumbricoides and T. trichuria. The highest intensity of infection was in the children at the age of 3-5 years living in bad hygienic conditions. The most common clinical manifestations in patients included anaemia in combination with bronchopneumonia, colitis and gastritis. The highest correlation between parasitic load and level of eosinophils, haemoglobin, and total iron was found in the children at the age of 2 years. The authors suppose that analysis of

Table 4 Levels of IgE, Eo, Lym, CRP in individual groups of paediatric patients with respiratory disease and infected with protozoa, or helminths

\begin{tabular}{|c|c|c|c|c|c|c|c|c|c|c|}
\hline Group of patients & Number & $\begin{array}{l}\text { IgE }> \\
\text { No. }\end{array}$ & $\begin{array}{l}\chi \text { test } \\
(\mathrm{P}) *\end{array}$ & $\begin{array}{l}\text { Eo> } \\
\text { No. }\end{array}$ & $\begin{array}{l}\chi \text { test } \\
(\mathbf{P})^{*}\end{array}$ & $\begin{array}{c}\text { Lym> } \\
\text { No. }\end{array}$ & $\begin{array}{l}\chi \text { test } \\
(\mathrm{P}) *\end{array}$ & $\begin{array}{c}\text { IgE }+ \text { Eo> } \\
\text { No. }\end{array}$ & $\begin{array}{c}\text { CRP> } \\
\text { No. }\end{array}$ & $\begin{array}{l}\chi \text { test } \\
(\mathbf{P}) *\end{array}$ \\
\hline Inf. with protozoa & 34 & 7 & 0.825 & 8 & 0.737 & 6 & 0.061 & 15 & 8 & 0.185 \\
\hline Inf. with helminths & 20 & 8 & 0.044 & 9 & 0.028 & 8 & 0.012 & 17 & 4 & 0.003 \\
\hline $\begin{array}{l}\text { Inf. with protozoa and } \\
\text { helminths }\end{array}$ & 54 & 15 & 0.257 & 17 & 0.192 & 14 & 0.315 & 32 & 12 & 0.682 \\
\hline Negative samples & 218 & 45 & 0.257 & 50 & 0.192 & 72 & 0.315 & 95 & 43 & 0.682 \\
\hline
\end{tabular}

Reference values

IgE $1-12$ months of age $<15$ IU/1; $2-5$ years of age $<60$ IU/1; $6-9$ years of age $<90$ IU/1; $10-15$ years of age $<200$ IU/1

Eo $1-5 \%$

Lym year of age $44-56 \% ; 3-6$ years of age $40-52 \% ; 7-12$ years of age $36-50 \%$

CRP month -15 years of age $<3 \mathrm{mg} / 1 ;>15$ years of age $<8 \mathrm{mg} / 1$

* $\chi$ test, $\mathrm{P}$ value $(\mathrm{P}<0.05)$, level of significance $(\alpha=0,05)$. Statistical significance of differences of increased levels of IgE, Eo, and Lym

between patients with positive and negative ovoscopic findings for protozoa or helminths 
laboratory parameters and clinical manifestations could contribute to specification of the diagnostics of parasitoses in children.

The increased levels of reference values of IgE, Eo, Lym, CRP could direct attention to the diagnostics of some species of tissue helminthoses (Ascaris, Toxocara, Ancylostoma, Necator, Strongyloides) in pulmonary tissue at their entero-hepato-pulmonary migration, because they can cause so-called eosinophilic pneumonitis. The high levels of total IgE antibodies connected with ascariosis limit the evidence supporting of this test in diagnostics of allergy. The diagnostic significance at some tissue helminthoses at the syndrome larva migrans, or others is also ascribed to the changes in the value of C-reactive protein (Kinčeková et al., 2008).

Several studies have dealt with the serum concentration of $\operatorname{IgE}$ in the patients infected with helminths or protozoa. The increased concentration of $\operatorname{IgE}$ antibodies was found especially in the patients with helminth infections (Di Prisco et al., 1993; Perlmann et al., 1994). Immunoglobu$\operatorname{lin} \mathrm{E}(\mathrm{IgE})$ is present in the serum in trace amounts under physiological condition, and has very short half-life $(2.5$ days). Occasionally, there are increased levels of $\operatorname{IgE}$ also at some protozoal infections (giardiosis). The levels of total serum $\operatorname{IgE}$ could be increased in case of atopic diseases, tumorous diseases, immunodeficient states, viral infections, which was also confirmed by our study. Concentration of $\operatorname{IgE}$ is also influenced by age, sex, race, socio-economical conditions, and it could differ in various countries. Therefore, our observed groups of paediatric patients were selected from the comparable socio-economical environment. The value of total $\operatorname{IgE}$ in the serum of children infected with $G$. intestinalis and E. vermicularis was significantly higher compared to the control group of healthy children (Kennedy, 2000).

Eosiniphilia is very frequent reaction of a host to helminth invasion, but it is rare in protozoal infections. The high levels of eosinophils can be in the patients with trichinelosis, ascariosis, filariosis, schistosomiosis, toxocarosis and fasciolidosis. In the developed countries parasitoses affect mostly children with immuno-deficient status, suffering from chronic, infectious, allergic, and autoimmune diseases (Hagel et al., 1993). Eosinophilia (up to $80 \%$ ) is found especially during acute phase of infection with helminths, in chronic phase of infection there is its gradual decrease (Kolářová, 2010).

Hassanein et al. (2013) studied the prevalence of endoparasitoses in children with acute lymphatic leukaemia and compared it with the prevalence in the control group of immunocompetent children. The incidence of parasitic infections in leukaemic children was by $30 \%$ higher (by $20 \%$ higher incidence of protozoal infections, and by $10 \%$ higher incidence of helminth infections). This can be caused by the fact that intestinal helminths induce the immune response of Th-2 type. The Th2 immune response can have a key role at influencing the seriousness of acute disease (e.g. pulmonary) during infection with helminths. The immune response of a host to helminth infection cor- relates with production of interleukins IL-4, IL-5, IL-9, IL10, and IL-13. The humoral immune response to parasites on that account can support infection with Mycobacterium tuberculosis. Positive regulation of Th2 response, including eosinophilia and hyperglobulinemia $\operatorname{IgE}$ induced by helminth infection can suppress production of Th1 of immune reaction that is important for fight against intra-cellular pathogens, such as e.g. M. tuberculosis (Demirci et al., 2002; Kaji et al., 2007; Dvorožňáková, 2012).

In immunocompromised people the seriousness and manifestations of some parasitic diseases can be altered. Infection with helminths (A. lumbricoides, A. duodenale, $T$. trichuria) are most widespread, especially in developing countries in the children suffering from malnutrition, infections and deficiency diseases (WHO, 2005; Vincent, 2005). Protozoal infections cause high morbidity in children, and as opportune infections in HIV/AIDS, and in immunosuppressed patients. In consequence of it the patients suffer from recurrent serious diarrhoeic states that can be fatal. C. parvum, G. intestinalis, E. histolytica are the most frequent agents of the diarrhoea.

\section{Acknowledgements}

This study was supported and co-financed from grant projects VEGA 1/0501/13

\section{References}

BeneŠ, J., BARTOŠOVÁ, D., BERAn, J., ČERnÝ, Z., DOSTÁL, V., Galský, J., HabAnec, T., HobstovÁ, J., HolČíKOVÁ, A., Holub, M., Honerg, K., HorÁK, M., Husa, P., ChAlupa, P., Chmelík, V., Krbková, L., Kümpel, P., MACHAla, L., MAREŠOVÁ, V., PíCHA, D., PlíŠEK, S., RozSYPAL, H., RoŽNOVSKÝ, L., SEDLÁČEK, L., STAŇKOVÁ, M., STEJSKAL, F., TÁBORSKÁ, J., VANIŠTA, J. (2009): Infectious Medicine. Praha, Galén: 325 - 458

Demirci, M., Korkmaz, M., SAKru, M., Kaya, S., KUMAN, A. (2002): Diagnostic importance of serological methods and eosinophilia in tissue parasites. J. Health Popul. Nutr., 20 (4): 352 - 355

Di Prisco, M., C., HAgel, I., LyNCH, N., R., BARrios, R., M., Alvarez, M., LóPez, R. (1993): Possible relationship between allergic disease and infection by Giardia lamblia. Ann J. Allergy, 70: 210 - 213

DVOROŽŇÁKOVÁ, E. (2012): Immunomodulators and their effects at parasitic infections. Slovak Veterinary Journal, 6: 318 - 321 (In Slovak)

Hagel, I., LynCh, N., R., Di PRISCO, M., C., LOPEZ, R., I., GARCIA, N., M. (1993): Allergic reactivity of children of different socioeconomic levels in tropical populations. Int. Arch. Allergy Immunol., 101: 209 - 214

Hassanein, F., Shaibat-El-Hamd, Z., El-Masry, S. (2013): Acute Lymphocytic Leukemia and Ecto- and Endo- Parasites: Association of acute lymphocytic leukemia in children with some Ecto-and Endo-parasites. Alexandria, Lambert Academic Publishing: 35 - 120. ISBN13: 978-3-659-21270-3 
Chaudhry, Z. H., Afzal, M., Malik, M. A. (2004): Epidemiological factors affecting prevalence of intestinal parasites in children of Muzaffarabad district. Pakistan J. Zool., 36 (4): $267-271$

Juriš, P., Rudohradská, P., PAPAJOVÁ, I. Bugri, Š., PriBiŠOVÁ, E., LAUKOVÁ, P., ČISLÁKOVÁ, L., HalanOVÁ, M., VARGOVÁ, V. (2012): Excrements contaminated soil as a source of infection diseases in the villages with hygienic standard: Social work, nursing and public health in the region Eastern Slovakia (EU) II.: 174 - 178. ISBN 978-808132-044-6

Kaji, K., YoshiI, H., Yoshikawa, M., Yamazaki, M., IKenaKa, Y., Noguchi, R., SAWAi, M., IshiKaWA, M., Mashitani, T., Kitade, M., Kawaratani, H., Uemura, M., Yamao, J., Fujimoto, M., Mitoro, A., Toyohara, M., YoshidA, M, FUKUI, H. (2007): Eosinophilic cholecystitis along with pericarditis caused by Ascaris lumbricoides: A case report. World J. Gastroenterol., 13 (27): $3760-3762$

Kalu, M., K., Eugene, C., N., Ifeanyi, A., O. (2013). Intestinal nematode parasites amongst school children attending some primary schools in Mbaitoli local Government area, imo state, Nigeria. J. Biol. Sci. Bioconservation, 5 (1): $102-110$

KENNEDY, M. W. (2000): Immune response to Anisakis simplex and other ascarid nematodes. Allergy, 55(Suppl. 59):7 - 13. DOI: 10.1034/j.1398-9995.2000.03402.x.

KinčeKovÁ, J., BÁnovČin, P., Fedor, M., Dubinský, P., Jr., PolÁČeK, H., PAVlinovÁ, J., ŠimekovÁ, K. (2008): A case of complicated cerebral toxocariasis in a 4-year old child. Helminthologia, 45 (4): 169 - 172. DOI: 10.2478/s11687-008-0034-z

KönigovÁ, A., KinČEKovÁ, J., HrČKOVÁ, G., VelebnÝ, M., VÁrady, M., PavlinovÁ, J., Kuchta, M. (2010): Nematode infections in Slovak children hospitalised during 2008 - 2009. Helminthologia, 47(4): 204 - 211. DOI: 10.2478/s11687-010-0032-9

RECEIVED FEBRUARY 16, 2014
O’Harhay, M., Horton, J., L Olliaro, P. (2010): Epidemiology and control of human gastrointestinal parasites in children. Exper. Rev. Anti. Infect. Ther., 8 (2): 219 - 234. DOI: 10.1586/eri.09.119

ONDRAŠOVIČ, M., JURIŠ, P., PAPAJOVÁ, I., ONDRAŠOVIČOVÁ, O., ĎUREČKO, R. (2002): Lethal effect of selected disinfectans on Ascaris suum eggs. Helminthologia, 29 (4): $205-209$

Perlmann, H., Helmby, H., Hagstedt, M., Elghazali, G., Worku, S., Fernandez, V., Rutta, A., S., TroyeBlomberG, M. (1994): IgE elevation and IgE antimalarial antibodies in Plasmodium falciparum malaria association of high IgE levels with cerebral malaria. Clin. Exp. Immunol. (England), 97: $284-292$

RiMÁrovÁ, K. (2010): The Health of the Roma People in Central and Eastern Europe. Košice, Equilibria: 24 - 26.

Rudohradská, P., HalánOVÁ, M., RAVASZOVÁ P., GoldovÁ., M, VALENČÁKOVÁ, A., HALÁN, M., PAPAJOVÁ, I., Pohorencová, A. VAlKo,J., ČISLÁKOVÁ, L., Juriš, P. (2012): Prevalence of intestinal parasites in children from minority group with low hygienic standards in Slovakia. Helminthologia, 49 (2): 63 - 66. DOI:10.2478/s11687012-0013-2

Shuji, S., Shida, Y., Takahashi, N., YabuUchi, H., Soeda, H., OKafuji, T., Hatakenaka, M., Honda, H. (2006): Pulmonary lesions associated with visceral larva migrans due to Ascaris suum or Toxocara canis: Imaging of six cases. AJR, 186: 1697 - 1702. DOI: 10.2214/AJR.04.1507

VINCENT W. F. (2005): Ascaris lumbricoides - the giant roundworm of man. Inf. Dis. Update: Medical News, 12 (5): $28-34$

World Health ORganization (2005): Deworming for Health and Development. Report of the third global meeting of the partners for parasite control. Geneva, WHO: $2-51$ 